\title{
MORTALITY COMPARISON OF USING ANTI INTERLEUKIN-6 THERAPY AND USING STANDARD TREATMENT IN SEVERE COVID-19
}

\author{
Jonathan Christianto Sutadji ${ }^{1}$, Agung Dwi Wahyu Widodo ${ }^{2}$, Danti Nur Indiastuti ${ }^{3}$ \\ ${ }^{1}$ Faculty of Medicine, Universitas Airlangga, Surabaya, Indonesia \\ ${ }^{2}$ Department of Microbiology, Faculty of Medicine, Universitas Airlangga, Surabaya, Indonesia \\ ${ }^{3}$ Department of Pharmacology, Faculty of Medicine, Universitas Airlangga, Surabaya, Indonesia
}

\section{ABSTRACT}

Severe Coronavirus Disease 19 (COVID-19) can cause serious lung inflammation and death. COVID-19 has been characterized by a very high mortality rate. This severity is associated with the overproduction of proinflammatory cytokines called "cytokine storms". One of the cytokines that play a central role is Interleukin-6 (IL-6). High IL-6 levels are associated with mortality. It is hoped that the IL-6 blockade can reduce cytokine storms and thus reduce deaths in severe COVID-19 patients. The aim of this systematic review was to summarize the comparison of mortality from using anti-IL-6 therapy with using standard treatment in severe COVID-19 patients. We systematically searched the PubMed, ScienceDirect, and ProQuest database until 13 August 2020. After screening, twelve studies matched the inclusion criteria. The mortality of the anti IL-6 therapy group was lower than the standard treatment group without anti IL-6 therapy in COVID-19 patients in 10 of the 12 studies obtained. Four of the ten studies found a statistically significant difference in mortality between the anti IL-6 therapy group and the standard treatment group. Confirmation of anti IL-6 therapy effectiveness in reducing mortality in severe COVID-19 patients will require randomized controlled trials.

Keywords: covid-19; SARS-CoV-2; terapi anti IL-6; inhibitor IL-6; mortality

\section{ABSTRAK}

Coronavirus Disease 19 (COVID-19) yang parah dapat menyebabkan peradangan paru-paru berat hingga kematian. Kematian pada COVID-19 ini cukup tinggi. Tingkat keparahan ini terkait dengan produksi berlebihan sitokin proinflamasi yang disebut "badai sitokin". Salah satu sitokin yang berperan sentral adalah Interleukin-6 (IL-6). Kadar IL-6 yang tinggi berhubungan dengan kematian. Blokade IL-6 diharapkan dapat meredam badai sitokin sehingga mengurangi kematian pada pasien parah COVID-19. Tujuan dari systematic review ini adalah untuk merangkum perbandingan kematian pada penggunaan terapi anti IL-6 dengan penggunaan pengobatan standar pada pasien COVID-19 berat. Pencarian literatur secara sistematis di database Proquest, PubMed, dan Science Direct hingga 13 Agustus 2020. Setelah dilakukan screening, didapatkan dua belas studi yang sesuai dengan kriteria inklusi. Kematian kelompok terapi anti IL-6 lebih rendah daripada kelompok pengobatan standar tanpa terapi anti IL-6 pada pasien COVID-19 pada 10 dari 12 studi yang didapatkan. Empat dari sepuluh studi tersebut mendapatkan perbedaan kematian yang secara statistik signifikan antara kelompok terapi anti IL-6 dan kelompok pengobatan standar. Konfirmasi efektivitas terapi anti IL-6 dalam mengurangi kematian pada pasien COVID-19 yang berat memerlukan uji coba terkontrol secara acak.

Kata kunci: covid-19; SARS-CoV-2; terapi anti IL-6; inhibitor IL-6; mortalitas

Correspondence: Agung Dwi Wahyu Widodo, Department of Microbiology, Faculty of Medicine, Universitas Airlangga, Surabaya, Indonesia. Email: agungimunologi@gmail.com

pISSN:2355-8393 • eISSN: 2599-056x • doi: 10.20473/fmi.v57i2.21929

- Fol Med Indones. 2021;57:158-165 • Received 08 Sept 2020 • Accepted 03 Dec 2020

- Open access under CC-BY-NC-SA license • Available at https://e-journal.unair.ac.id/FMI/ 


\section{INTRODUCTION}

Coronavirus Disease 2019 (COVID-19), caused by severe acute respiratory syndrome coronavirus 2 (SARS-CoV-2), has spread widely around the world (Ge et al 2020). People with COVID-19 can have a wide range of symptoms, from mild symptoms to severe illness (CDC 2020). In severe cases, SARS-CoV-2 virus can cause serious lung inflammation, acute respiratory distress syndrome (ARDS), multi-organ failure, and death (Tufan et al 2020; Zhou et al 2020). COVID-19 has been characterized by a high mortality rate. The main cause of death was interstitial pneumonia with respiratory failure (De Rossi et al 2020).

The severity of COVID-19 patients associated with the excessive production of pro-inflammatory cytokines called "cytokine storms". The cytokine storm will cause shock, respiratory failure, multiple organ failure, and finally lead to death in severe COVID-19 cases. These pro-inflammatory cytokines are IFN- $\alpha$, IFN- $\gamma$, IL- $1 \beta$, IL-2, IL-6, IL-12, TNF- $\alpha$, and others (Tufan et al 2020, $\mathrm{Li}$ et al 2020). From these pro-inflammatory cytokine, interleukin-6 (IL-6) plays a key role in the pathogenesis of the COVID-19 related cytokine storm (Coperchini et al 2020).

High IL-6 levels are often found in severe COVID-19 patients (Antwi-Amoabeng et al 2020). Elevated serum IL-6 correlates with respiratory failure, ARDS, and adverse clinical outcomes (Moore \& June 2020). Moreover, IL-6 is significantly associated with mortality (Klopfenstein T et al 2020). IL-6 blockade is a promising strategy for COVID-19 related cytokine storm (Liu et al 2020). Therefore, this study was conducted to review the comparison of mortality from using anti-IL-6 therapy with using standard treatment in severe COVID-19 patients.

\section{MATERIALS AND METHODS}

This systematic review was conducted in accordance with the Preferred Reporting Items for Systematic Reviews and Meta-Analyses (PRISMA) guidelines. We systematically searched the PubMed, ScienceDirect, and ProQuest database until 13 August 2020. The key terms searched were "Mortality" AND ("COVID-19" OR "SARS-CoV-2") AND ("Anti IL-6 therapy" OR "IL-6 inhibitor" OR "Tocilizumab" OR "Sarilumab").

We retrieved all the studies comparing the mortality of the anti IL-6 therapy and control group for severe COVID-19 patients. We excluded preprints that were yet to undergo peer-review, case reports, review, editorials, correspondences, and commentary types of articles, studies that did not report mortality outcomes with anti IL-6 therapy in severe COVID-19, and studies that did not compare mortality outcomes for anti IL-6 therapy compared with placebo or control.

Furthermore, the extracted relevant data from all the retrieved studies were collected and tabulated using Microsoft Excel. The extracted information included the name of the first author, title, study design, study site, patients demographic characteristics, the regimen of anti IL-6 therapy and comparative agents, and mortality outcome.

\section{RESULTS}

\section{Search Results}

The search strategy initially resulted 1187 articles. After removing 78 duplicates, 1109 articles were subsequently screened by title and abstract. Finally, 37 articles were identified for full-text review for eligibility. Twelve retrospective studies were designed to compare the mortality outcome for anti IL-6 therapy and its comparators in the treatment of severe COVID19 patients, thus were included in this systematic review (Figure 1).

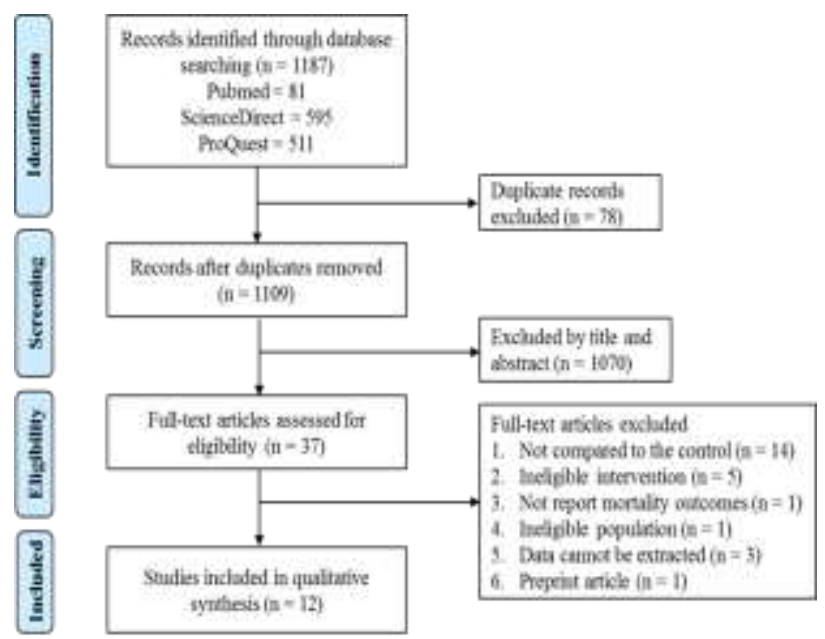

Figure 1. Flow diagram of study selection

\section{Characteristics of the Involved Studies}

The characteristics of the included studies are shown in Table 1. Six studies were conducted in Italy. The remaining 6 studies were from USA $(n=3)$, France $(n=2)$, and Spain $(n=1)$. In addition, only 2 studies were multicenter and the remaining 10 studies were singlecenter. The included studies had a wide range of sample sizes from 45 to 544 . The median/mean ages of subjects were above 50 years old in all studies. Except for one 
study that used sarilumab, eleven studies used tocilizumab as an anti IL-6 regimen. Tocilizumab 400 $\mathrm{mg}$ or $8 \mathrm{mg} / \mathrm{kg}$ intravenously was the most commonly reported regimen of tocilizumab.

\section{Mortality Outcome}

The mortality data in the articles among severe COVID19 patients are summarized in Table 1 . The reported mortality of COVID-19 patients with anti IL-6 therapy from the included studies were very broad and ranged from $3.22 \%$ to $52 \%$. While, the mortality in the control group ranged from $1.9 \%$ to $62 \%$. In twelve retrospective studies, ten of the twelve studies found that mortality was lower in the anti IL-6 therapy compared to the control group. Four of the ten studies found a lower mortality in the anti IL-6 therapy which was statistically significant. This supports the reduction in mortality from the use of anti IL-6 therapy, especially in the study conducted by Guaraldi et al (2020) which had a large enough sample of 544 patients $(\mathrm{p}=0.0007)$.

Meanwhile, in six of the ten studies, there were no significant differences in mortality. However, mortality was lower in the group receiving anti IL-6 therapy. Interestingly, the two Klopfenstein et al's (2020) study found that the combined primary endpoint (death and/or ICU admission; mortality and/or IMV requirement) was lower in the Tocilizumab group which was statistically significant even though the patients in the Tocilizumab group had a more severe condition. In addition, in the study by Rojas-Marte et al (2020), mortality was significant lower in the Tocilizumab group when the intubated patients were excluded. A study conducted by Canziani et al (2020) had a significant lower risk of invasive ventilation at 30 days in the Tocilizumab group. 


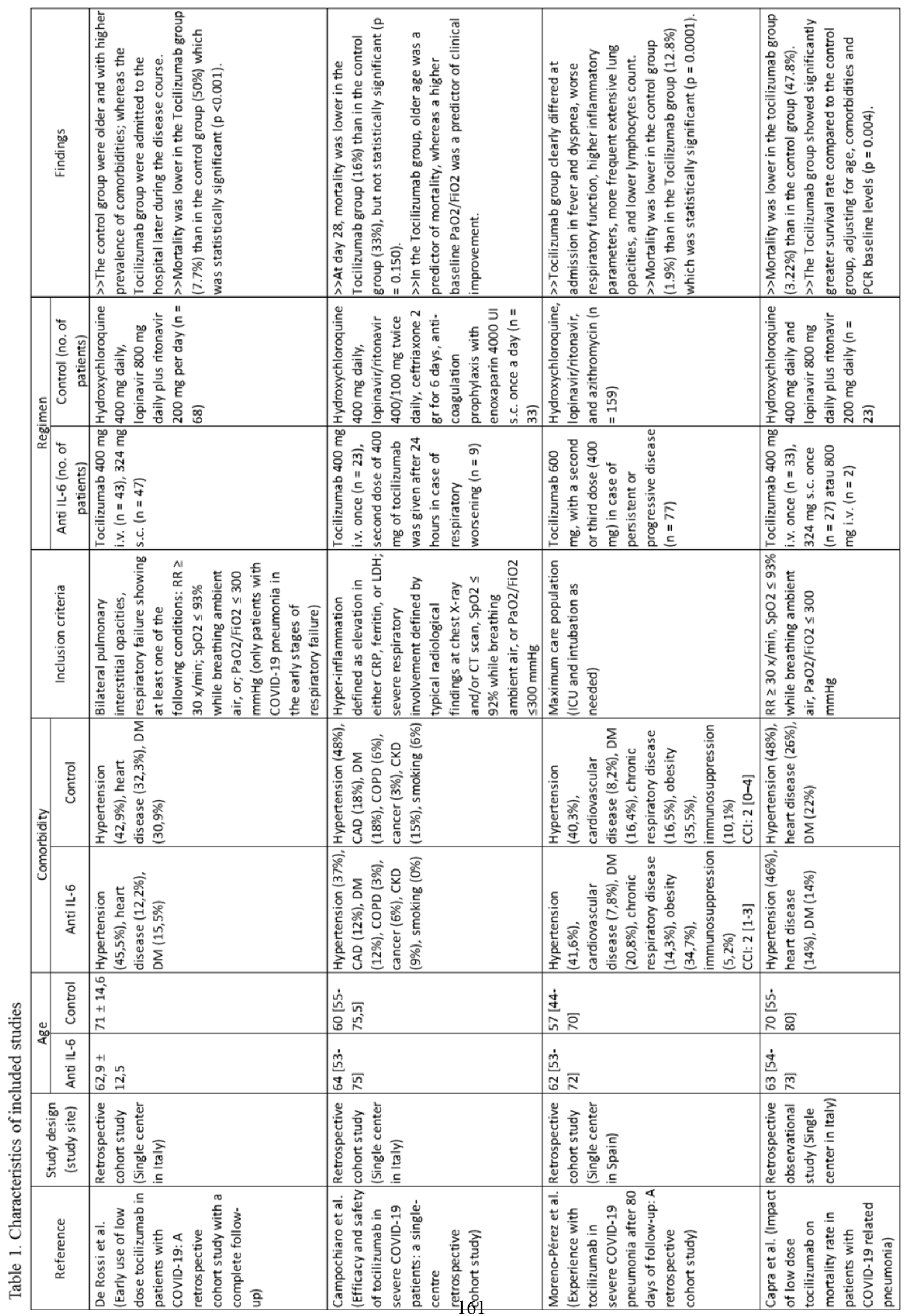




\begin{tabular}{|c|c|c|c|c|}
\hline 害 & 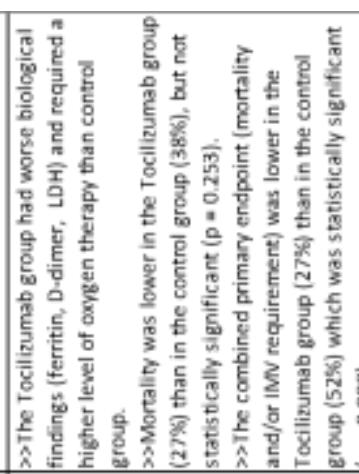 & 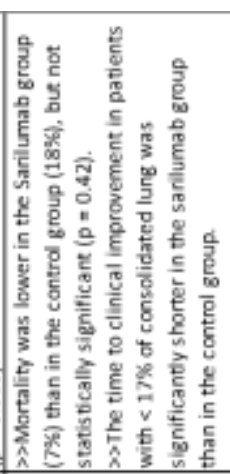 & 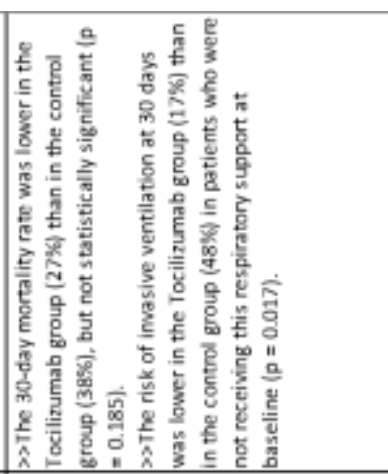 & 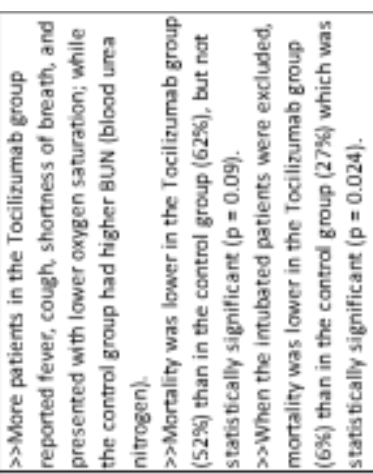 \\
\hline 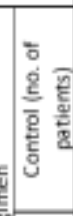 & 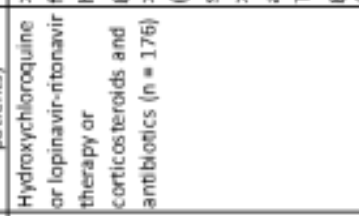 & 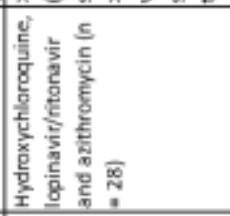 & 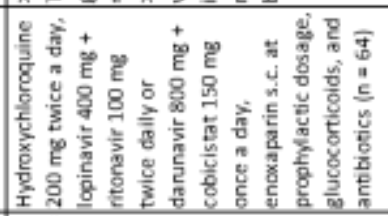 & 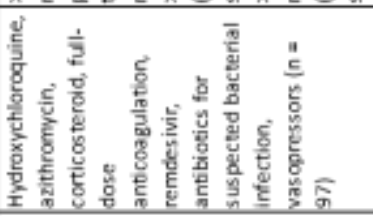 \\
\hline 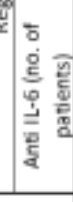 & 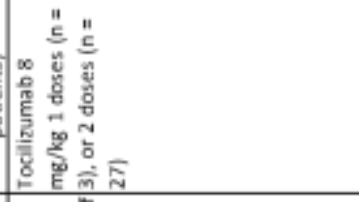 & 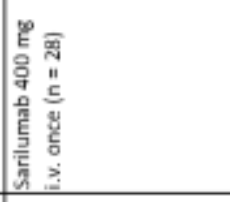 & 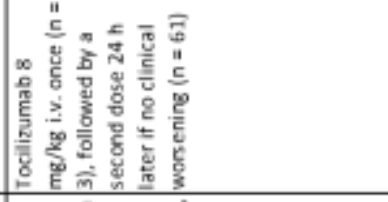 & 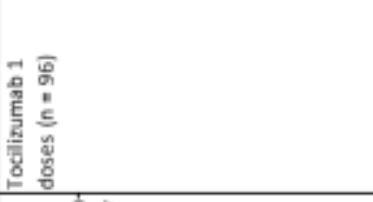 \\
\hline 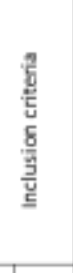 & 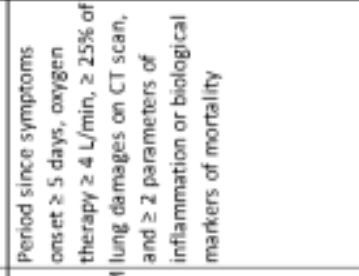 & 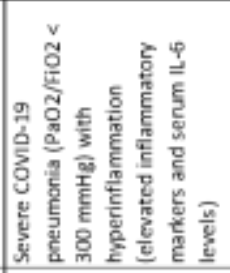 & 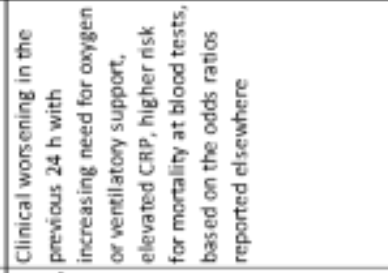 & 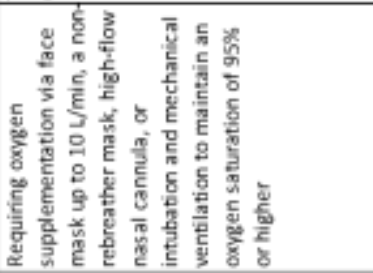 \\
\hline$=$ & 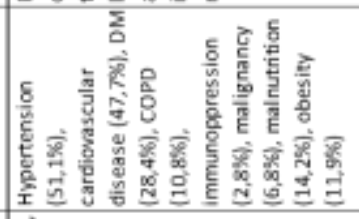 & 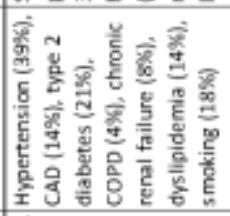 & 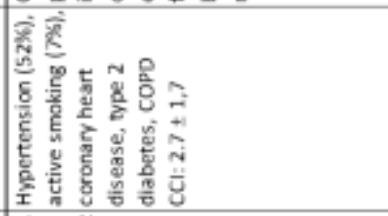 & 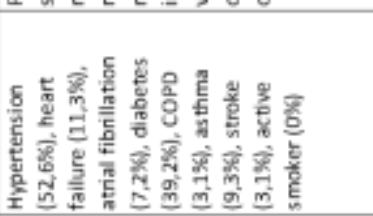 \\
\hline 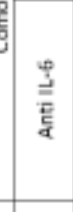 & 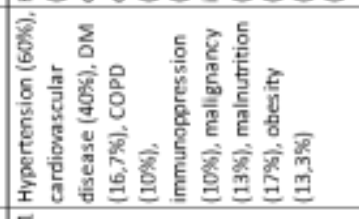 & 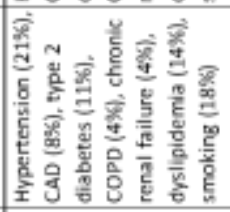 & 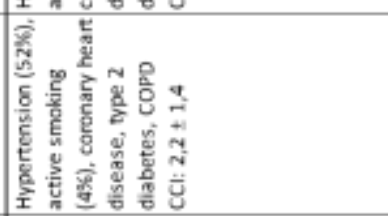 & 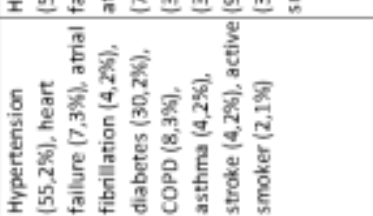 \\
\hline \begin{tabular}{|l}
$\bar{g}$ \\
$\bar{c}$ \\
$\bar{g}$
\end{tabular} & 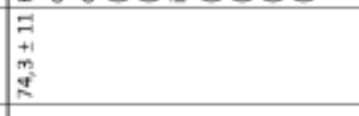 & 究宫 & $\begin{array}{l}\infty \\
\vdots \\
\vdots \\
0 \\
\end{array}$ & \\
\hline 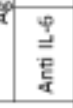 & \begin{tabular}{ll}
+1 \\
0 \\
0 \\
\hdashline
\end{tabular} & 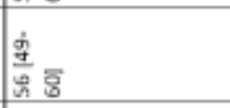 & $\begin{array}{l}\approx \\
\pm \\
1 \\
B\end{array}$ & 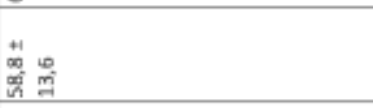 \\
\hline 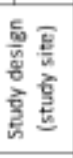 & 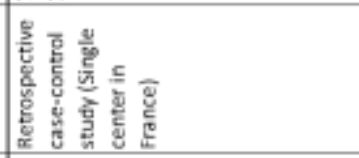 & 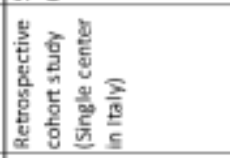 & 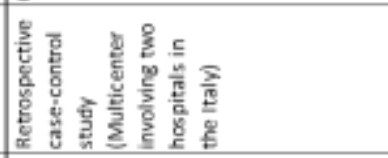 & 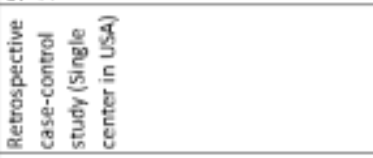 \\
\hline 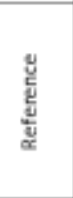 & 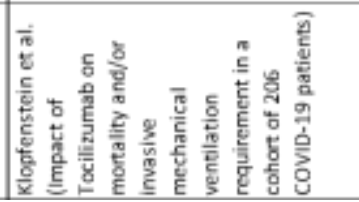 & 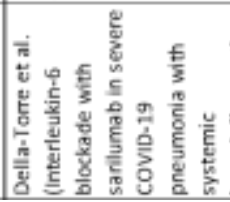 & 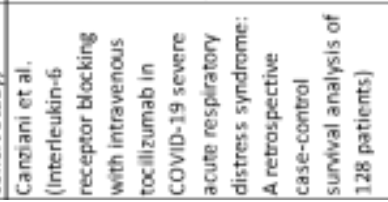 & 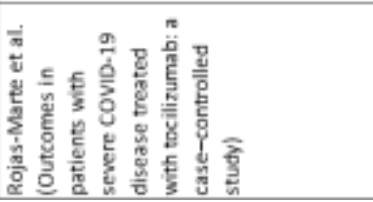 \\
\hline
\end{tabular}




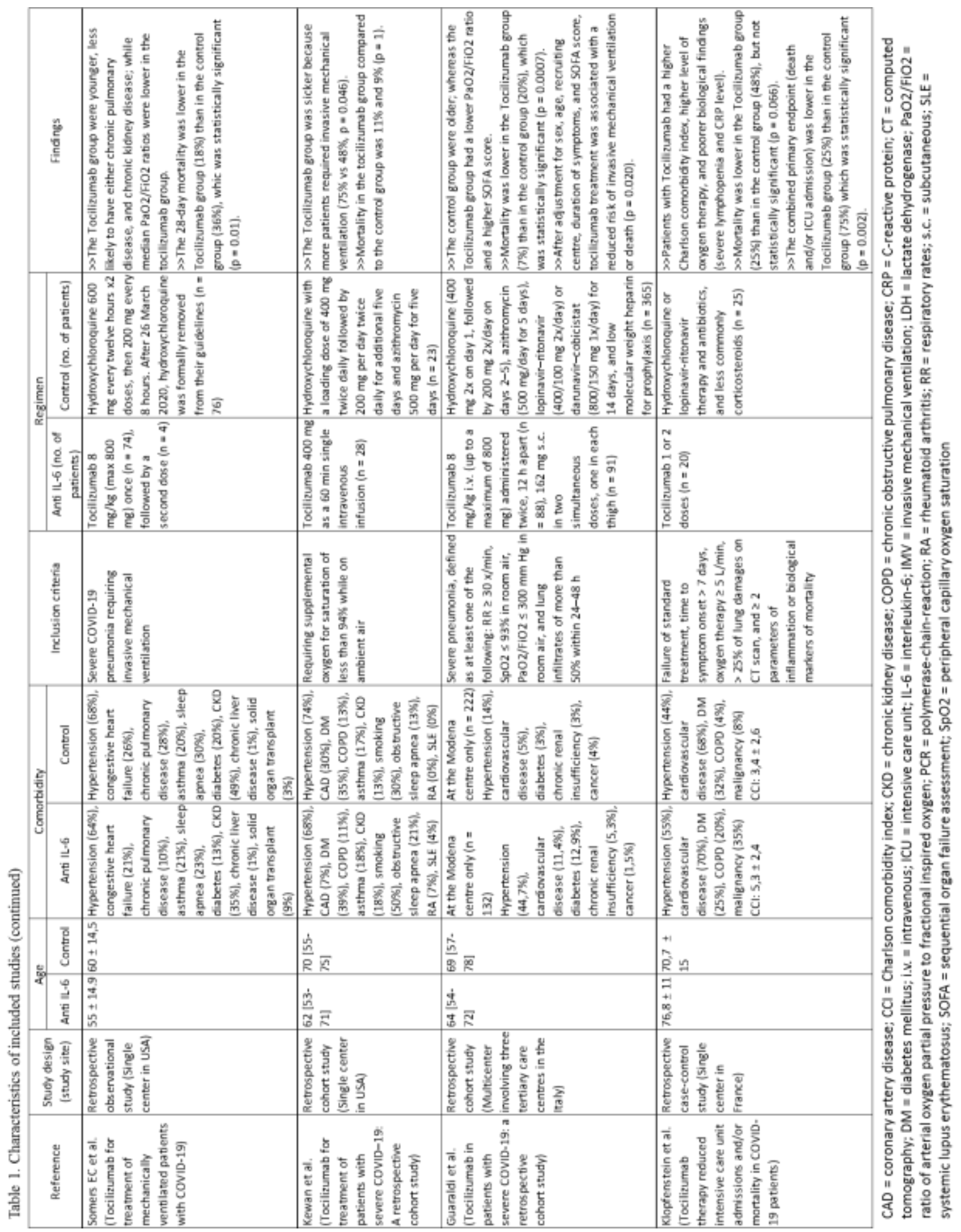




\section{DISCUSSION}

In this study, we review the effect of anti IL-6 therapy in reducing severe COVID-19 mortality. Our findings supported the effectiveness of anti IL-6 therapy in the prevention or treatment of COVID-19 induced cytokine storms that lead to death. Ten of the twelve studies we reviewed found lower mortality in the anti IL- 6 therapy than control group although not all of them were statistically significant. The low number of patients in the study probably explains that the difference in mortality was not significant because of the lack of statistical power.

IL- 6 is one of the most important cytokines involved in COVID- 19 induced cytokine storms that cause acute respiratory disesase syndrome (ARDS), multiple organ dysfunction, and death rapidly (Luo et al 2020, Tufan et al 2020). IL-6 blockade is a promising strategy for COVID-19 induced cytokine storms (Liu et al 2020). A retrospective observational study by Luo et al (2020) supported the effectiveness of Tocilizumab in the prevention or treatment of cytokine storms in COVID19 patients. The gradual decrease in IL-6 reflects an improvement in the condition of most patients after Tocilizumab administration, although a persistent and dramatic increase in IL-6 was observed in some critically ill patients who failed treatment. There may exist an upper threshold beyond that cause this persistent increase in IL-6. Rapid control of hyperinflammation can result in clinical improvement in some of patients (Antwi-Amoabeng et al 2020). Therefore, early treatment with Tocilizumab, one of the anti IL-6 therapies, could be helpful to prevent excessive hyperinflammation and death in severe COVID-19 patients (Capra et al 2020, De Rossi et al 2020).

This systematic review had several limitations that must be considered. First, all studies in this systematic review were retrospective non-randomized studies. Second, the clinical characteristics of the anti IL-6 therapy group and the control group were not homogeneous. Third, the inclusion criteria for COVID-19 patients in each study were also different. This was related to the timing of anti IL-6 therapy which could affect the outcome of severe COVID-19 patients. Fourth, the treatment given to both standard treatment and anti IL-6 therapy was not the same in dose and frequency. Fifth, the low number of patients in most studies led to ambiguous results. Therefore, a larger randomized controlled study was needed to clarify the effectiveness of anti IL- 6 therapy in reducing mortality in severe COVID-19 patients.

\section{CONCLUSION}

We found lower mortality on the use of anti-il-6 therapy compared with standard treatment in 10 of the 12 available studies, but a larger randomized controlled study was needed to clarify the effectiveness of anti IL6 therapy in reducing mortality in severe COVID-19 patients.

\section{ACKNOWLEDGMENT}

It is grateful to the Director of Aisyiyah Hospital Bojonegoro, Ethical Team, and patients who involved in this study. The grateful to the Dean of the Faculty of Pharmacy Universitas Airlangga, and as well as lecturer staff of Clinical Pharmacy Master Program Faculty of Pharmacy Universitas Airlangga.

\section{REFERENCES}

Antwi-Amoabeng D, Kanji Z, Ford B et al (2020). Clinical outcomes in covid-19 patients treated with tocilizumab: An individual patient data systematic review. Journal of Medical Virology. Available from https://onlinelibrary.wiley.com/doi/10.1002/jmv.2603 8. Accessed August 12, 2020

Canziani LM, Trovati S, Brunetta E, et al (2020). Interleukin-6 receptor blocking with intravenous tocilizumab in COVID-19 severe acute respiratory distress syndrome: A retrospective case-control survival analysis of 128 patients. Journal of autoimmunity 114, 1-7.

Capra R, De Rossi N, Mattioli F, et al (2020). Impact of low dose tocilizumab on mortality rate in patients with COVID-19 related pneumonia. European Journal of Internal Medicine 76, 31-35.

CDC (2020). Coronavirus disease 2019 (COVID-19): Symptoms. centers for disease control and prevention. Available from https://www.cdc.gov/coronavirus/2019ncov/symptoms-testing/symptoms.html. Accessed August 12, 2020

Coperchini F, Chiovato L, Croce L, et al (2020). The cytokine storm in COVID-19: An overview of the involvement of the chemokine/chemokine-receptor system. Cytokine Growth Factor Reviews 53, 25-32.

De Rossi N, Scarpazza C, Filippini C, et al (2020). Early use of low dose tocilizumab in patients with COVID-19: A retrospective cohort study with a complete follow-up. E-clinical Medicine 25, 1-9.

Ge H, Wang X, Yuan X, et al (2020). The epidemiology and clinical information about COVID-19. European 
Journal of Clinical Microbiology \& Infectious Diseases 39, 1011-1019.

Guaraldi G, Meschiari M, Cozzi-Lepri A, et al (2020). Tocilizumab in patients with severe COVID-19: a retrospective cohort study. The Lancet Rheumatology 2, e474-e484

Klopfenstein T, Zayet S, Lohse A, et al (2020). Impact of tocilizumab on mortality and/or invasive mechanical ventilation requirement in a cohort of 206 COVID-19 patients. International Journal of Infectious Diseases 99, 491-495.

Klopfenstein T, Zayet S, Lohse A, et al (2020). Tocilizumab therapy reduced intensive care unit admissions and/or mortality in COVID-19 patients. Medecine et Maladies Infectieuses 50, 397-400.

Li X, Geng M, Peng Y, et al (2020). Molecular immune pathogenesis and diagnosis of COVID-19. Journal of Pharmaceutical Analysis 10, 102-108.

Liu B, Li M, Zhou Z, et al (2020). Can we use interleukin-6 (IL-6) blockade for coronavirus disease
2019 (COVID-19)-induced cytokine release syndrome (CRS)?. Journal of Autoimmunity 111, 1-9.

Luo P, Liu Y, Qiu L, et al (2020). Tocilizumab treatment in COVID-19: A single center experience. Journal of Medical Virology 92, 814-818.

Moore JB, June CH (2020). Cytokine release syndrome in severe COVID-19. Science 368, 473-474.

Rojas-Marte G, Khalid M, Mukhtar O, et al (2020). Outcomes in patients with severe COVID-19 disease treated with tocilizumab: A case-controlled study. QJM 113, 546-550.

Tufan A, Avanoğlu GA, Matucci-Cerinic M (2020). Covid-19, immune system response, hyperinflammation and repurposing antirheumatic drugs. Turkish Journal of Medical Sciences 50, 620632.

Zhou F, Yu T, Du R, et al (2020). Clinical course and risk factors for mortality of adult inpatients with COVID-19 in Wuhan, China: a retrospective cohort study. The Lancet 395, 1054-1062. 